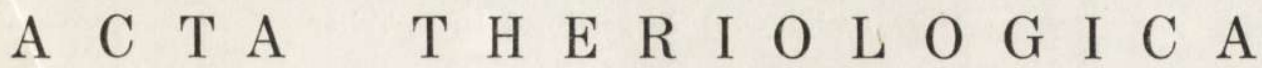

\author{
H. Duane S M ITH, Clive D. J OR G EN SEN \\ \& H. Dennis TOLLEY
}

\section{Estimation of Small Mammal Using Recapture Methods: Partitioning of Estimator Variables ${ }^{1}$}

\author{
[With 1 Fig.]
}

\begin{abstract}
A model was developed to estimate small mammal densities when capture-recapture methods are used to gather the data. The model includes a grid design surrounded by a dense line of traps to detect movement of animals into and out of the grid. If movement is detected into or out of the grid, dispersal behavior, death rate, trap avoidance, and animal-trap relationships are determined and partitioned to provide the most reliable density estimates. If there is no movement or it is not detected, the density estimates would likely be less reliable. Both the field design and the estimator are coordinated to provide a reliable estimate without home range data. This model seems most useful in studies where permanent or semi-permanent grids are established in populations that cannot be disturbed by removal or kill trapping.
\end{abstract}

\section{INTRODUCTION}

Estimating densities of small mammals and other animals in their natural environments is complicated with population variables such as dispersal, death rates, trap avoidance, and animal-trap relationships, which themselves are variously confounded. This confounding stimulates numerous questions concerning the validity of existing estimators and probably includes the reasons why results of work using these estimators have not been satisfactorily duplicated or predicted. It is likely that partitioning of these variables will be required before precise estimators can be developed. This is particularly true when one has to use capture-recapture methods to avoid reducing the population.

1 This study was supported, in part, by a National Science Foundation Grant to Utah State University for IBP Desert Biome Studies. The work was conducted at Brigham Young University as part of subcontract No. 9007 with Utah State University. 
Several recent attempts (Calhoun \& Casby, 1958; Janion, Ryszkowski \& Wierzbowska, 1968; Jolly, 1963, 1965; Leslie, 1952; Tanaka, 1963; Tanaka \& Kanamori, 1967; $\mathrm{T}$ a $\mathrm{n}$ t o $\mathrm{n}, 1965,1969)$ have been made to generate raliable estimators, but none have taken full advantage of the benefits inherent in coordinating the estimator with the field design. Past attempts have been restricted largely to developing mathematical rationale and procedure that can be used with recapture data, however they are obtained.

This study provides a proposed field design and subsequent analyses that complement each other so that the confounding of variables is greatly reduced and appropriately partitioned. This method should be particularly helpful in studies where permanent or semi-permanent study plots must be maintained.

\section{FIELD DESIGN}

The basic field design is a $12 \times 12$ grid completely surrounded by a dense line ${ }^{2}$ (Fig. 1). The grid size and the number of stations may vary to accommodate the species to be studied, providing each station on the grid contains two traps.

Dispersal into and of the grid is estimated with the dense line, which can detect which animals move. A perimeter line ${ }^{3}$ is established between the border of the grid and the dense line. The perimeter line is used to determine precisely which of the animals trapped in the grid and/or the dense line should be counted as residents of the grid; thus, becoming a part of the density estimate.

The rationale for the dense line is easier to understand after the methods have been defined for determining how far the dense line should be from the grid border. Line $X$ of the dense line is established $a$ units from the grid border; where $a$ is determined by using the recapture radii for all animal classes of interest. The estimates for recapture radii with .95 confidence are determined by methods proposed by Burge \& Jorgensen (1970). Where recapture radii $(r)$ are not known or are known to differ among the classes, $a$ would be expected to be unknown or different for each class. Fortunately, it is not necessary to know, the precise values for $r$ since the field design can be adjusted

\footnotetext{
2 The dense line (Fig. 1) is actually three lines $(X, Y, Z)$ of traps that completely surround the grid. The two inner-most ( $X$ and $Y$ ) maintain trap spacing and number ( 2 per station) comparable to the grid, but the outer-most $(Z)$ may have one trap per station and the stations are much closer together. The distance between $Y$ and $Z$ is arbitrary, providing it is less than $b$.

3 The perimeter line is imaginary since it cantains no traps and is situated mid-way between the border of the grid and the dense line (specifically $X$ ).
} 
during sampling to compensate for any error that might have been made. The limitations imposed by $a$ are rather broad, so that several classes can be sampled simultaneously, unless the differences in their respective $r$ values are extreme. If $b$ is the distance between trapping stations in the grid, and $r_{l}$ and $r_{h}$ represent the classes with estimates of the lowest and highest recapture radii $(r)$, respectively; then $a$ is chosen so that $\left(r_{h}-b\right)<a / 2<r_{l}$. When $a$ is chosen with these specifications, the area actually trapped by the grid can be accurately determined since animals

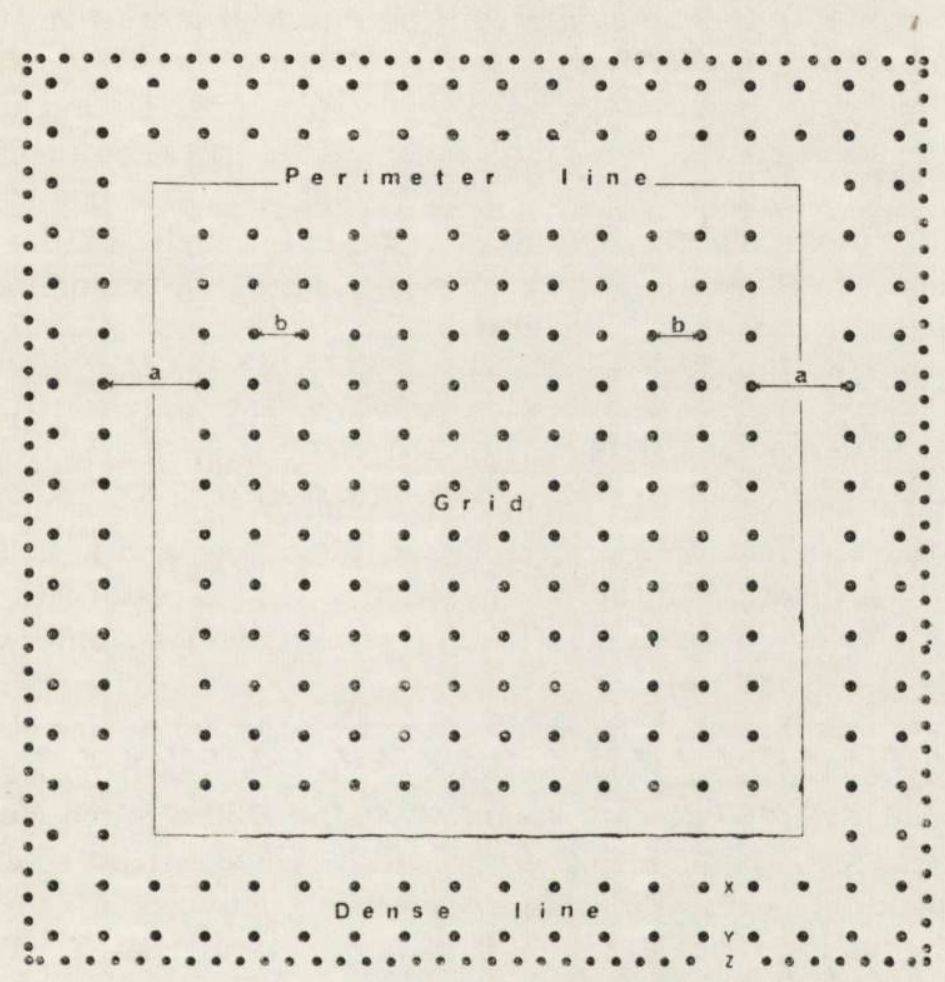

Fig. 1. Schematic diagram of the grid and dense line design. The dense line is made up three (3) lines $-X, Y$, and $Z$ from the innermost to the outermost. The perimeter line is imaginary and contains no traps.

with the recapture radius $r_{l}$ will be trapped on the grid - their centers of activity are inside the perimeter line; and animals with the recapture radius $r_{h}$ are not likely to move from the $Z$ line area to the grid in their normal movement. Whenever possible, $a$ should be a multiple of $b$ since this will simplify establishing the dense line around the grid. This can be done by adjusting the spacing $(b)$ of traps on the grid and/or by adjusting $a$. 
The advantages of this design in estimating densities are evident. It is not necessary to obtain home range data since only those animals whose centers of activity are truly on or inside the perimeter line are counted among the residents of the grid. Thus, it is not necessary to expand the grid by some factor estimated as a function of the home range. Assuming that an animal moves randomly, if its center of activity is right on the perimeter line, one would expect that $50 \%$ of its captures would be on the dense line and $50 \%$ on the grid. It is unlikely (because of the method for determining $a$ ) that an animal will be captured more than two trap-lines from its center of activity.

According to the laws of probability, if an animal is caught at least $60 \%$ of the time on the dense line, one can be $95 \%$ confident that its activity center is outside of the perimeter line and it is not included in density estimates even on those days when it is caught on the grid. All animals that are caught less than $60 \%$ of the time on the dense line are considered to be residents of the grid.

The perimeter line is basically independent of the activity radii for the different classes under consideration, but if one must use an $a$ which is excessive, grid densities for classes with very small $r$ values may have to be determined with grid expansion techniques, since $a$ may be too large for these animals to reach the dense line or the grid if their centers of activity are directly on the perimeter line. It is necessary to use $r_{h}$ in estimating $a$ if one is interested in that particular class; otherwise, data concerning it are not useful.

When animals that are frequently caught on the $Z$ line are also caught periodically within the boundary traps of the grid (with no signs of directional movement), one may assume that the $Z$ line is too close to the grid and $a$ is too small. This condition can be corrected by re-estimating $a$ and expanding it or by placing another line between $X$ and $Y$ which has spacing identical to $X$ and is $b$ distance away from $X$. The latter method provides for a wider dense line with more traps, but also provides density estimates for classes with rather small $r$ values.

\section{ANALYTICAL METHODS}

With confidence established in the area being sampled, one must now estimate the population size within that area, and this can be done while taking full advantage of the information from the dense line. Previous estimators that included mortality Leslie, 1952; J olly, 1963; 1965) have several behavioral and population characteristias confounded in this one function. This study will attempt to partition mortality, dispersal, and trap avoidance from this confounding. It must be kept in mind that 
this partitioning is based on stochastic procedures and should not be considered absolute for any given animal.

The primary function of population estimators is to estimate the number of animals $\left(N_{i}\right)$ at time $i$, and since a proportional index procedure is used with capture-recapture data, this index must be established first. If $\Psi_{i}$ is the proportion of marked to unmarked animals in the grid population at time $i$, then $\Psi_{i}$ can be estimated with

$$
\Psi_{i}=\frac{m_{i}}{n_{i}}
$$

where: $m_{i}=$ the number of animals caught at time $i$ that were previously marked, and

$n_{i}=$ the number of animals caught in the sample at time $i$, from data provided by animals caught on the grid, or if data from the dense line are available with

$$
\Psi_{i}=\frac{M_{i-1}-\delta_{i}\left(l_{i}+d_{i}\right)+s_{i-1}}{N_{i-1}+k_{i}-\left(l_{i}+d_{i}\right)}
$$

where: $M_{i}=$ the number of marked animals in the population at the beginning of trapping time $i$,

$l_{i}=$ the number of animals leaving the grid between time $i-1$ and $i$,

$d_{i}=$ the number of animals that died on the grid between time $i-1$ and $i$,

$s_{i}=$ the number of $n_{i}$ animals that were newly marked and released at time $i$, and

$k_{i}=$ the number of animals coming onto the grid between time $i-1$ and $i$.

The proportion of animals marked at the beginning of the nest trapping day is provided with

$$
\delta_{i+1}=\Psi_{i}+\frac{s_{i}}{N_{i}}
$$

It is assumed that animals will respond similarly to traps on the grid and on the dense line. This response (expressed as a probability) may vary from $i \ldots i_{n}$, but it cannot change substantially between the dense line and the grid on any given day. Since this probability $\left(\Phi_{i}\right)$ is essentially what provides the basis for estimating $N_{i}$ when $N_{i+1}=n_{i+1} / \Phi_{i+1}$, it must be solved for. 
The proportion of marked to unmarked animals in the population at time $i$ can now be shown equivalent to

$$
\Psi_{i}=\frac{l_{t i}}{P_{t o t i}-p k_{i}}
$$

where: $l_{t i}=$ the number of animals caught for the first time on the dense line at time $i$, that had previously been caught on the grid, and that subsequently disappeared,

$P_{t o t i}=$ the number of animals caught on the dense line at time $i$, that are not residents of the dense line or do not remain residents of the dense line, and

$p k_{i}=$ the number of animals moving onto the grid that were marked on the dense line at time $i$.

One can conveniently solve for $p k_{i}$ with

$$
p k_{i}=\frac{\Psi_{i} P_{t o t i}-l_{t i}}{\Psi_{i}}
$$

Now that $p k_{i}$ is solved, and $k_{t i}$ is defined as the number of animals moving onto the grid that were trapped on the dense line at time $i$ and then on the grid at time $i+1$, one can obtain $k_{t i}$ as the product of $\Phi_{i}$ and $p k_{i}$. Consequently $\Phi_{i}$ can be obtained with

$$
\Phi_{i}=\frac{k_{t i}}{p k_{i}}
$$

$N_{i+1}$ can now be obtained since $N_{i+1}=n_{i+1} / \Phi_{i+1}$, and an estimate of the population on the grid is available.

This population estimate may (and often will) change among the trapping days necessary to obtain a reliable estimate with confidence. The number of trapping days depends to some extent on the animal-trap behavior and how long it takes to obtain useful data for the species of concern. It would appear that a minimum of 10 days are required, particularly if one requires maximum partitioning of the variables mentioned earlier. The change in the population size $\left(\Delta N_{i}\right)$ from time $i-1$ to $i$ is simply the difference between the two days.

$$
\Delta N_{i}=N_{i}-N_{\mathrm{i}-1}=\frac{n_{i}}{\Phi_{i}}-\frac{n_{i-1}}{\Phi_{i-1}}
$$

and assuming the young animals just entering the trappable population can be identiffied, the change may be attributed to the numbers of trappable animals coming onto, leaving, and dying from on the grid. Thus, $\Delta N_{i}$ may be redefined as $\Delta N_{i}=k_{i}-d_{i}-l_{i}$. 
This partitioning of $\Delta N_{i}$ must be solved if one wants to know the reason for the estimated changes. It might also be recalled that the solution to this equation will provide an estimate of mortality rate and dispersal rate within classes of trappable animals. Assuming the young animals just entering the trappable population can be determined, it is possible to assess further what is providing for $k_{i}$ since $d_{i}+l_{i}=k_{i}-\Delta N_{i}$. Substituting this statement in equation 2 , one obtains

$$
\Psi_{i}=\frac{M_{i-1}-\delta_{i}\left(k_{i}-\Delta N_{i}\right)+s_{i-1}}{N_{i-1}+k_{i}-\left(k_{i}-\Delta N_{i}\right)}
$$

Since the ratio $M_{i} / N_{i}$ is equivalent to $m_{i} / n_{i}, M_{i}$ can be solved and substituted into equation 8 to provide the solution for $k_{i}$

$$
k_{i}=\frac{-\Psi_{i} N_{i-1}-\Delta N_{i} \Psi_{i}+s_{i-1}+M_{i-1}+\delta_{i} \Delta N_{i}}{\delta_{i}}
$$

Once $k_{i}$ has been solved, one can solve for the probability of an animal being caught on the dense line during time $i\left(p_{i}\right)$ with $p_{i}=p k_{i} / k_{i}$, which can be used to solve for the total movement onto and off from the grid. The total movement is estimated with $P_{\text {toti }}=P_{i} l_{i}+p k_{i}$, and $l_{i}$ is conveniently provided as

$$
l_{i}=\frac{P_{t o t i}-p k_{i}}{p_{i}}
$$

Mortality rates are then obtained by 'simply solving $d_{i}=k_{i}-\Delta N_{i}-l_{i}$.

Basically, if movement is detected, estimates for $N_{i}$ and $\Delta N_{i}$ can be conveniently obtained. Also, $\Delta N_{i}$ can be partitioned into $d_{i}$ (mortality rate), $l_{i}$ (number of animals leaving the grid), and $k_{i}$ (number of animals coming onto the grid). It is possible to partition $d_{i}$ further to estimate trap avoidance $\left(a_{i}\right)$ and separate this from the pooled likelihood that an animal died, estivated, etc. If an animal is caught at time $i$ and was not recaptured before the sampling period (time $t$ ) ended, it either died, left the grid undetected by the dense line, or avoided recapture for $t-i$ days.

The probability that it left the grid undetected may be estimated with:

$$
q_{i}=\sum_{j=i+1}^{t}(1-p) \frac{l_{j}}{N_{j-1}}
$$

Now the probability that it stayed on the grid, but simply avoided the traps $\left(a_{i}\right)$ may be estimated as the product of the probability that it was not trapped and the probability that it stayed on the grid. This is obtained with: 


$$
a_{i}=\stackrel{\mathrm{t}}{\Pi}_{j=i+1}\left(1-\Phi_{j}\right) q_{i}
$$

When $q_{i}$ and $a_{i}$ are estimated, a new probability of mortality $\left(d_{i}^{\prime}\right)$ may be obtained with $\left(1-a_{i}-q_{i}\right)$. This estimate may then be used to estimate mortality rates in the naturally existing population during the trapping period. This estimate is obviously separate from trap kills. One must always consider that $d_{i}^{\prime}$ also includes animals that are not at risk because of estivation.

When movement is not detected on the dense line, except for only one day, Jolly's (1965) estimate of $\Phi_{i}\left(=p_{i}\right.$ of Jolly, 1965) can be used to provide an estimate of $N_{i}$ if $m_{i}$ does not vary appreciably. For days when movement is detected in either direction on the dense line, one can estimate $p_{i}, l_{i}, k_{i}, d_{i}$, and $d_{i}^{\prime}$. If one can assume a constant relative efficiency of the grid to the dense line, it may be defined with $C=\Phi_{i} / p_{i}$, and used to provide an estimate of $p_{i}=\Phi_{i} / C$ for days where movement data are not available. Again, this uses Jolly's (1965) estimate of $\Phi_{i}$. With $p_{i}$ solved on days of undetected movement, it follows that $1-p_{i}$ is the probability of having the maximum $l_{i}$ animals move through the dense line undetected is provided with $\left(1-p_{i}\right) l_{i}>.05$ at the .95 confidence interval. By using Jolly's (1965) $B_{i}$, which is the number of animals dispersed, a .95 confidence interval can also be placed on the minimum $d_{i(\min )}=B_{i}-l_{i(\max )}$, and since $k_{i(\max )}$ equals $l_{i(\max )}, l_{i(\max )}$ can also be solved.

An estimate of population number should be accompanied by an appropriate confidence statement. Since the estimates of $N_{i}$ inside the grid are based on a simple binomial model with parameter $\Phi_{i}$, one can use a normal approximation of a confidence interval around the real parameter estimated by $\Phi_{i}$. This relationship is readily obtained with:

$$
N(0,1)=\frac{\hat{\Phi}_{i}-\Phi_{i}}{\sqrt{\frac{\hat{\Phi}_{i}\left(1-\hat{\Phi}_{i}\right)}{p k_{i-1}}}}
$$

This is further expressed as a confidence on $N_{i}$ with:

$$
\mathrm{p}\left[-\mathrm{Z}_{\alpha / 2}<\frac{\hat{\Phi}_{i}-\Phi_{i}}{\sqrt{\frac{\hat{\Phi}_{i}\left(1-\hat{\Phi}_{i}\right)}{p k_{i-1}}}}\right]=1-\alpha
$$


or:

$\mathrm{p}\left[\hat{\Phi}_{i}-\mathrm{Z}_{\alpha / 2}\left(\sqrt{\frac{\hat{\Phi}_{i}\left(1-\hat{\Phi}_{i}\right)}{p k_{i-1}}}\right)<\Phi_{i}<\hat{\Phi}_{i}-\mathrm{Z}_{\alpha / 2}\left(\sqrt{\frac{\hat{\Phi}_{i}\left(1-\hat{\Phi}_{i}\right)}{p k_{i-1}}}\right)\right]=1-\alpha$

By inverting and multiplying by $n_{i}$, since $N_{i}=n_{i}\left(1 / \Phi_{i}\right)$, a confidence on $N_{i}$ may be obtained with:

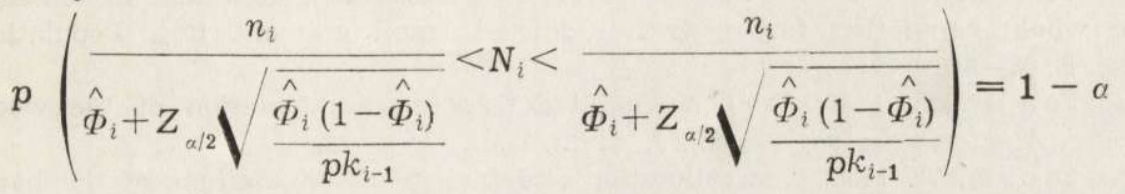

In cases where $p k_{i}$ is high, this confidence expression is good, but if $p k_{i}$ is small (resulting from no detectable movement), J olly's (1965) variance estimate should be used since his approximates a maximum likelihood estimate. Consider the following two cases:

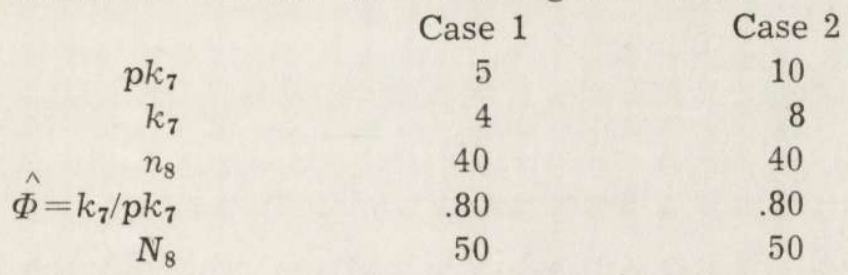

In case 1 :

$$
\boldsymbol{p}\left(\frac{40}{.80+1.96 \sqrt{\frac{(.80)(.20)}{5}}}<\mathrm{N}_{8}<\frac{40}{.80-1.96 \sqrt{\frac{(.80)(.20)}{5}}}\right)=.95
$$

or $p(35<50<85)$. In case $2, p(39<50<69)$ is a much improved statement. The confidence in case 1 is too broad to be particularly useful and probably should have used Jolly's (1965) variance estimate. The skewed confidence interval is due to $\Phi_{i}=.80$, thus it might be better to use the actual binomial since the normal approximation is best at $\Phi_{i} \approx .50$.

\section{REFERENCES}

1. Burge J. R. \& Jorgensen C. D., 1970: Home range of small mammals a reliable estimate. (manuscript in review).

2. Calhoun J. B. \& Casby J. U., 1958: The sampling of populations of small mammals with reference to home range movements. U. S. Publ. Hlth. Monograph 55: $1-33$.

3. Janion M., Ryszkowski L. \& Wierzbowska T., 1968: Estimate of number of rodents with variable probability of capture. Acta theriol. 13: $285-293$.

4. Jolly G. M., 1963: Estimates of population parameters from multiple recapture data with death and dilution - deterministic model. Biometrika 50: $113-128$.

Acta theriol. 5 
5. J olly G. M., 1965: Explicit estimates from capture-recapture data with both death and immigration - stochastic model. Biometrika 52: 225-247.

6. Leslie P. H., 1962: The estimation od population parameters from data obtained by means of the capture-recapture method. II. The estimation of total numbers. Biometrika 39: 363-388.

7. Tanaka R., 1963: On the problem of trap-response types of small mammal populations. Res. Population Ecol. 5: 139-146.

8. Tanaka R. \& Kanamori M., 1967: New regression formulae to estimate the whole population for recapture-addicted small animals. Res. Population Ecol. 9: 83-94.

9. Tanton M. T., 1965: Problems of live trapping a population of the wood mouse, Apodemus sylvaticus (L). J. Anim. Ecol. 34: 1-22.

10. Tanton M. T., 1969: The estimation and biology of populations of the bank vole (Clethrionomys glareolus ( $\mathrm{S} \mathrm{chr}$.)) and wood mouse (Apodemus sylvaticus (L.)). J. Anim. Ecol. 38: 511-529.

Accepted, October 19, 1971.

Center of Environmental Studies,

Brigham Young University,

Provo, Utah 84601 , USA

H. Duane SMITH, Clive D. JORGENSEN i H. Dennis TOLLEY

OCENA LICZEBNOSCI MAEYCH SSAKOW METODA POWTORNYCH ZEOWIEN: PODZIAE ESTYMATORA

\section{Streszczenie}

Ocena zagęszczenia małych ssaków jest skomplikowana z uwagi na trudności uzyskania dokładnych informacji odnośnie takich zmiennych populacji jak struktura przestrzenna, tempo wymierania, unikanie pułapki i stosunki zwierzę-pułapka. Największe trudności istnieją w ocenie śmiertelności, zmiennej ważnej dla oceny zagęszczenia, a często obejmującej również inne parametry.

Charakterystyki populacji, zostały $w$ tej pracy usystematyzowane pod kątem uzyskania ocen: prawdopodobieństwa złowienia $(\Phi)$, ilości zwierząt w terenie $(N)$, ilości zwierząt, które opuściły powierzchnię w czasie połowów $(l)$, ilości zwierząt. które naszły na powierzchnię w czasie połowów $(k)$, ilości zwierząt, które padły na powierzchni w czasie połowów (d) i ilości zwierząt na powierzchni a unikających pulapki $(a)$.

Powierzchnie odłowne (Ryc. 1) winne być otoczone trzema rzędami pułapełs ( dense line"). Jeżeli stwierdzi się migracje zwierząt przez tę strefę zagęszczonych pułapek, to możliwe jest ocenienie wyżej opisanych parametrów oraz wielkości populacji. Jeżeli jednak nie wykryje się takich migracji to oceny zawierać będą mylne charakterystyki i będą mniej realne.

Omawiana metoda może być odpowiednio modyfikowana i stosowana odnośnie wszystkich małych ssaków, które mogą być schwytane w pułapki żywołowne. Bardzo wskazanym jest, by $w$ badaniach ciągłych powierzchnia badawcza była czynna w tym samym miejscu raczej dłuższy okres czasu i by populacja nie byla zakłócana przez usuwanie lub zabijanie zwierząt. 